\title{
Eucalyptus AND Acacia SPECIES AND FUTURE STRATEGIES FOR IMPROVEMENT IN THE UP COUNTRY OF SRI LANKA
}

\author{
K M A Bandara \\ Research Officer, Forest Department \\ Passara Road, Badulla.
}

Most of the arable lands in up country are used for tea and some other cash crops like vegetables. The land available for commercial reforestation is marginal and degraded. However, commercially valuable tree species like Eucalyptus and Acacia are planted in the tea plantations as an additional income source: to produce a significant timber and luel wood production.

Naturally available tree species cannol be cultivated commercially due to their slow growth and poor timber quality. Furthermore, Michelia champara, Cedrella toona and Arlocarpus heterophyllas that are locilised to up country show slow growth and are therefore very difficult to plant as commercial trees.

Fast growing Eucalyptus and Acaria species have becn introduced to up country in the 1800s. E. grandis and E. microcorys species are planted in the up country in large-scale industriat plantations and in the farmlands. Hence they produce significant production for the timber market. Acacia species are not planted widely in this zone but there will be a high potential for the species $A$. nelamorylom in the luture as a fumiture timber tree.

Genetic improvement of Eucalyptus stanted in 1980s. E.grandis, E.microcorys, E. clocziana and $E$. arophylla have shown promising growth in the species trials. Provenances of E. grandis from northern Queensland and provenances of E. microcorys from northern New South Wales have performed well. Broad range provenances of $A$. melamorylon trial have been established in the recent past.

A long term brecding programme for E.grandis was formulated in 1994. The first generation progeny trial was established in 1995 in the upcountry intermediate zone. Hence. it is proposed to convert that to a seedling seed orchard in the future. Two seed production areas for each species were established in two different climatic zones, Up country intermediate and wet zone for immediate seed requirements.

Present activities of tree improvement in the up country and future improvement strategies and plans will be discussed.

Preceedings of the Fomith Amural Forestry and Enviromment Symposium 1998 of the Departme'nt of

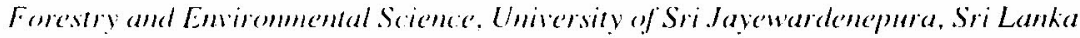

